This is an Open Access article distributed under the terms of the Creative CommonsAttribution 4.0 International License which permits unrestricted non-commercial use, distribution, and reproduction in any medium, provided the original work is properly cited.

http://ijnms.net/index.php/ijnms

\title{
EFFECT OF DIABETES SELF MANAGEMENT EDUCATION (DSME) ON KNOWLEDGE OF CONTROL OF BLOOD SUGAR IN DIABETES MELLITUS PATIENTS
}

*LutfiWahyuni,** Binarti Dwi

STIKes Bina Sehat PPNI Mojokerto

\section{ABSTRACT}

Many people who did not realize he had had a disease that was more often called diabetes or diabetes. This was caused by several factors, including the level of knowledge and education, behavior, eating habits, closeness and exposure to information sources. One form of education that was commonly used and proven to be effective in improving the clinical outcome and quality of life of diabetes mellitus patients were Diabetes Self Management Education (DSME). This study aimed to prove the influence of diabetes self-management education (DSME) to the knowledge of blood glucose control in people with diabetes mellitus in Gayaman Village and Kweden Village Work Area Health Center Gayaman Mojokerto. In this research, the design used was Pre-experiment with One Group Pre-Post Test Design approachment. The population was all DM patients in Gayaman Village and Kweden Village with 32 respondents. Samples from 32 respondents were taken using Total Sampling technique. Data collection techniques used questionnaires and data were analyzed using crosstabs. There is the influence of diabetes self-management education (DSME) to know about controlling blood sugar level in people with diabetes mellitus with value $3,1 \%$. Diabetes self-management education (DSME) can be an intervention in providing knowledge to patients with DM so that patients can control blood sugar levels well.
Keywords

Diabetes Self Management Education (DSME),

Diabetes Mellitus, Knowledge. 


\section{INTRODUCTION}

Diabetes mellitus as a metabolic abnormality caused by hormonal disorder characterized by elevated blood glucose levels (hyperglycemia) can cause various chronic complications in the eyes, kidneys, nerves, and blood vessels (Mansjoer, 2007). This is caused by several factors, including the level of knowledge, level of education, behavior, eating habits, closeness and exposure to information sources. People with diabetes mellitus who have minimal knowledge about diabetes will affect blood sugar levels and will lead to rapid complications, and this will be a burden for families and communities (Sulistyowati, 2009).

World Health Organization (WHO) predicts Indonesia will increase the number of people with Diabetes Mellitus from 8.4 million in 2000 to about 21.3 million in 2030 (Ernawati, 2013). Preliminary study results conducted by the researchers on 08 February 2017 at Health Center GayamanMojokerto found 120 patients with diabetes mellitus in the village, researchers took data in Gayaman Village there are 17 patients, and in Sweden Village, there are 15 patients with diabetes mellitus which some 32 patients from January 2016 until February 2017. Based on observations and interviews with patients suffering from diabetes mellitus conducted by researchers from 6 people taken, 4 people $(80 \%)$ said less know how to control blood sugar levels because patients do not perform treatment recommendations as well as not do regular exercise, do not take medication according to schedule or instructions from doctor, and do not do diet according to the recommendation of diet for DM patient, while 2 people $(20 \%)$ know how to control blood sugar level because in the process of treatment the patient to do the treatment well such as activate physical bag / regular exercise, taking medication regularly, but not doing DM dieting recommendation well.

One form of education that is commonly used and proven to be effective in improving clinical outcomes and the quality of life of diabetes mellitus patients is Diabetes Self Management Education (DSME) (McGown, 2011). Education about the management of DM disease provides an alternative option that may help control blood glucose levels better to prevent complications in diabetes mellitus patients. Therefore, researchers are interested in examining more deeply related to the influence of Diabetes Self Management Education (DSME) to the knowledge of blood sugar levels control in people with diabetes mellitus.

\section{RESEARCH METHOD}

The design of this research is preexperimental with one group pretest-posttest design approach. The total population is all people with diabetes Mellitus in Gayaman Village 17 Patients and Village Kweden 15 respondents. Sampling using nonprobability sampling technique that is total sampling. Measuring tool using questionnaires is a list of questions about the knowledge of blood sugar control consisting of 20 questions, then categorized good, enough, less. Time result is February 2017 until Mei 2017. Variable independent is diabetes self-management education (DSME), a Variable dependent is the knowledge of blood glucose control pasient diabetes.

Data analysis in this study using Cross Tab is used to see the difference and comparison of knowledge of blood sugar level control of 
diabetes mellitus patients before and after given treatment of Diabetes Self Management Education in Gayaman Village and Kweden Village Work Area of Gayaman Health Center Mojokerto.

\section{RESEARCH RESULT}

1. General Data

Table 4.1 Distribution of frequency of respondents by age.

\begin{tabular}{llll} 
No & Usia (tahun) & F & \% \\
\hline 1. & $31-36$ & 1 & $3,1 \%$ \\
2. & $37-42$ & 2 & $6,3 \%$ \\
3. & $43-48$ & 7 & $21,9 \%$ \\
4. & $49-54$ & 7 & $21,9 \%$ \\
5. & $55-60$ & 9 & $28,1 \%$ \\
6. & $61-68$ & 6 & $18,8 \%$ \\
\hline & Total & 32 & $100 \%$ \\
\hline
\end{tabular}

Based on the table found that almost half of respondents have age 55-60 years that is as much as nine respondents $(28.1 \%)$.

Table 4.2 Distribution of frequency of respondents by education.

\begin{tabular}{llll} 
No & Pendidikan & F & $\%$ \\
\hline 1. & Tidaksekolah & 2 & $6,3 \%$ \\
2. & SD & 12 & $37,5 \%$ \\
3. & SMP & 10 & $31,3 \%$ \\
4. & SMA & 8 & $25,0 \%$ \\
5. & PerguruanTinggi & 0 & $0 \%$
\end{tabular}

Total $32 \quad 100 \%$

Based on the above table it is found that almost half of respondents have elementary education as many as 12 respondents $(37.5 \%)$.

Table 4.3 Distribution of frequency of respondents based on information history.

\begin{tabular}{llll}
\hline No & RiwayatInformasi & F & \% \\
\hline 1. & Pernah & 14 & $43,8 \%$ \\
2. & Belum & 18 & $56,3 \%$ \\
\hline
\end{tabular}

$$
\text { Total }
$$$$
32 \quad 100 \%
$$

Based on the above table it is found that most respondents have not received information about DM control as much as 18 respondents $(56.3 \%)$.

\section{Special Data}

Table 4.4 Characteristics of respondents based on knowledge of blood sugar levels control before DSME

\begin{tabular}{llll}
\hline No & Kriteria Pengetahuan & F & \% \\
\hline 1. & Baik & 2 & $6,3 \%$ \\
2. & Cukup & 12 & $37,5 \%$ \\
3. & Kurang & 18 & $56,3 \%$ \\
\hline & Total & 32 & $100 \%$
\end{tabular}

Based on the above table it is found that most respondents have less knowledge that is as many as 18 respondents $(56.3 \%)$.

Table 4.5 Characteristics of respondents based on knowledge of blood sugar levels control after DSME.

\begin{tabular}{llll}
\hline No & KriteriaPengetahuan & F & \% \\
\hline 1. & Baik & 19 & $59,4 \%$ \\
2. & Cukup & 9 & $28,1 \%$ \\
3. & Kurang & 4 & $12,5 \%$ \\
\hline & Total & 30 & $100 \%$
\end{tabular}

Based on the above table it is found that most respondents have good knowledge as much as 19 respondents $(59,4 \%)$.

Table 4.6 Tabulation of control knowledge of blood sugar levels before and after DSME.

\begin{tabular}{lllll}
\hline Pengetahuan & \multicolumn{2}{l}{ Sebelum } & \multicolumn{2}{l}{ Sesudah } \\
\hline & F & \% & F & \% \\
\cline { 2 - 5 } Baik & 2 & $6,25 \%$ & 19 & $59,4 \%$ \\
CukupBaik & 12 & $37,5 \%$ & 9 & $28,1 \%$ \\
KurangBaik & 18 & $56,25 \%$ & 4 & $12,5 \%$ \\
\hline Total & $\mathbf{3 2}$ & $\mathbf{1 0 0 \%}$ & $\mathbf{3 2}$ & $\mathbf{1 0 0 \%}$ \\
\hline
\end{tabular}


1. Knowledge of blood sugar level control in DM patient after DSME did to DM patient in Gayaman Village and Kweden Village Working Area of GayamanMojokerto Health Clinic.

The results based on table 4.10 note that after DSME is done, most of the knowledge of respondents about blood sugar control as much as 19 respondents (59.4\%) who have good knowledge.

One of the pillars of diabetes mellitus treatment is education. Education plays a very important role in the management of diabetes mellitus because the provision of education to patients can help change the behavior of patients in managing diabetes independently. A gradual education is one aspect that can be implemented with Diabetes Self Management Education (DSME). Diabetes Self Management Education (DSME) is an effective form of education given to diabetes mellitus patients because Diabetes Self Management Education (DSME) has principles in its implementation.

Education plays a very important role in the management of diabetes mellitus because the provision of education to patients can help change behavior. The provision of Diabetes Self Management Education (DSME) can increase the knowledge, attitude, and behavior of patients in self-care (Funnell, 2008).

Based on the above explanation, it can be concluded that with the provision of Diabetes Self Management Education (DSME) can increase the knowledge of DM patients about blood sugar levels control.

\section{Effect of DSME on Knowledge of blood sugar level control in DM patient.}

Based on Table 4.11 it is known that there is a change of knowledge about blood sugar level control on the respondent before DSME done some respondents have less knowledge as much as 18 respondents $(56,25 \%)$, and after DSME activity some respondents have good knowledge as many as 19 respondents (59, $4 \%$ ). So the success rate of this DSME activity is $3.1 \%$.

Of the few respondents who before the treatment had less knowledge and after given the treatment of knowledge remained less as many as four respondents (12.5\%) due to respondents educated elementary school and there are no schools. And respondents also have not received information about blood control.

Of the few respondents who before the treatment had less knowledge and after given the treatment of knowledge became quite as much as 9 respondents $(28.12 \%)$, because the respondents are educated elementary school, but there are educated junior high and high school. And from the history of information, there is not yet get information about blood sugar levels control, and there is ever get information about controlling blood sugar levels.

Of the respondents who before the treatment had less knowledge and after given the treatment of knowledge to be good as much as five respondents $(15,6 \%)$ because of respondents had education elementary, junior high and high school but seen from history all respondents have got information about blood sugar. 
From the majority of respondents who before the treatment had enough knowledge and after given the treatment of knowledge to be good as many as 12 respondents $(37.5 \%)$ due to many respondents educated junior high and high school. And from the history of information many respondents who have received information about blood sugar levels control than those who have not received information about blood sugar levels control.

From the majority of respondents who before the treatment have good knowledge and after given the treatment of knowledge to be good as much as two respondents $(6.25 \%)$ due to high school educated respondents. And from the information history of respondents never get information about controlling blood sugar levels.

Knowledge of blood sugar level control before DSME mean value that is 54,69 and knowledge of blood sugar level control after done DSME mean value that is 76,41 . Knowledge of blood sugar level control before DSME median value is 55,00 and knowledge of blood sugar level control after DSME median value is 80,00 . Knowledge of blood sugar level control before DSME mode value that is 55 and knowledge about blood sugar level control after DSME mode value that is 80. So it is known that the average knowledge about blood sugar control in respondents before DSME is 54,69 and after done DSME that is 76,41 from result happened knowledge increase 21,72.

This shows an increase in response knowledge after being given DSME treatment. Thus, there is the influence of DSME on the knowledge of blood glucose control in DM patients in Gayaman Village and Kweden Village Work Area of Gayaman Health Center Mojokerto.

The level of formal education is the basis of intellectual knowledge possessed by a person. This is related to knowledge because the higher the knowledge of a person will be the more widely owned insight. Good level of knowledge

One of the pillars of diabetes mellitus treatment is education. Education plays a very important role in the management of diabetes mellitus because the provision of education to patients can help change the behavior of patients in managing diabetes independently. A gradual education is one aspect that can be implemented with Diabetes Self Management Education (DSME). Diabetes Self Management Education (DSME) is an effective form of education given to diabetes mellitus patients because Diabetes Self Management Education (DSME) has principles in its implementation.

Education plays a very important role in the management of diabetes mellitus because the provision of education to patients can help change behavior. The provision of Diabetes Self Management Education (DSME) can increase the knowledge, attitude, and behavior of patients in self-care (Funnell, 2008).

Based on the above explanation, it can be concluded that with the provision of Diabetes Self Management Education (DSME) can increase the knowledge of DM patients about blood sugar levels control. About controlling blood sugar levels will help individuals in suppressing symptoms of DM that appears. Information obtained from both formal and non-formal education can have a short-term 
effect, resulting in a change or increased knowledge. Obtaining information can speed up a person acquiring new knowledge. Information obtained by someone will stimulate one's mind and ability and increase knowledge. So the more easy and much information obtained by someone then one's knowledge of a thing will be more and more.

Diabetes Self Management Education (DSME) is an effective form of education given to diabetes mellitus patients because Diabetes Self Management Education (DSME) has principles in its implementation. Education plays a very important role in the management of diabetes mellitus because the provision of education to patients can help change behavior. The provision of Diabetes Self Management Education (DSME) can increase the knowledge, attitude, and behavior of patients in self-care (Funnell, 2008).

This can happen because the main principle of Diabetes Self Management Education (DSME) is effective diabetes mellitus education in improving clinical outcomes and patient quality of life even in the short term, Diabetes Self Management Education (DSME) has evolved from primary teaching models to more theoretically based on the model of patient empowerment, no best educational programs but educational programs that incorporate behavioral and psychosocial strategies have been shown to improve clinical outcomes, ongoing support is a very important aspect to sustain patient progress during the Diabetes Self Management Education (DSME) program, and the setting of behavioral goals is an effective strategy to support self-care behaviour.

\section{CONCLUSION AND SUGGESTION}

\section{Conclusion}

The results showed There is Influence of Diabetes Self Management Education to the knowledge about blood sugar level control in DM patient in Gayaman Village and Kweden Village Working Area of Gayaman Health Center. Before DSME, some respondents had less knowledge as much as 18 respondents (81.8\%), and after DSME activity some respondents had good knowledge as much as 19 respondents $(90,5 \%)$. So the success rate of this DSME activity is $8.7 \%$.

This can happen because the main principle of Diabetes Self Management Education (DSME) is effective diabetes mellitus education in improving clinical outcomes and patient quality of life even in the short term, Diabetes Self Management Education (DSME) has evolved from primary teaching models to more theoretically based on the model of patient empowerment. The provision of Diabetes Self Management Education (DSME) can improve the knowledge, attitude, and behavior of patients in self-care.

\section{Suggestions.}

For Respondents

It is expected that the results of this study can provide an effective effect on the DM patients in Gayaman Village and Kweden Village in obtaining other health information. DSME activities for respondents are used to improve knowledge about blood sugar levels control.

\section{For Educational Institutions}

It is expected that the results of this study can be used as a new group learning model and can provide other health education to students. Counseling or provision of information in the presence of such methods 
will provide a positive effect in providing changes - a better change to all patients with DM.

For Further Researchers

Expected to be used as a reference for other researchersdipenelitihan further to improve knowledge of patients with diabetes DM controlling the level of sugar.

\section{REFERENCES}

Aini, N. 2016. Nursing Care on Endocrine System with NANDA NIC NOC Approach. Jakarta: Salemba Medika

Bilous, Ruby W. 2008. Diabetes. Jakarta: Dian Rakyat.

Corwin, Elizabeth J. 2009. The Pathophysiology Pocket Book. Jakarta: EGC

Funnell, M. M., et.al. 2008. National Standards for Diabetes SelfManagement Education. Diabetes Care Volume 31 Supplement 1: p. S87-S94.

Heriansyah. 2014. Effect of Education With the Approach of the Principle of Diabetes Self Management Education (DSME) In Improving Diet Knowledge Of Diet Compliance In Type 2 Diabetes Mellitus Mender: Makassar: POLTEKES KEMENKES MAKASSAR

Herliana. (2013). Diabetes Herbal Blood Donation. Jakarta: F Media.
Hidayat, A. A Alimul. 2008. Introduction to Basic Concept of Nursing Edition 2. Jakarta: Salemba Medika.

Hidayat, A. A. (2007). Methods of Nursing Research and Data Analysis Techniques. Jakarta: Salemba Medika.

Jones, H., Berard, L. D., \& Nichol, H. 2008. Self-management Education. Canadian Journal of Diabetes Volume 32 Supplement 1: p. S25S28.

Ministry of Health RI. 2014. Indonesia Health Profile 2014. (http://www.depkes.go.id). (Accessed on January 9, 2017).

Mansjoer, e. A.2007. Kapita Selekta Medicine Volume 1 Issue 3. Jakarta: Media Aesculapins.

Maulana, H. D. J. 2009. Health Promotion. Jakarta: EGC.

McGown, P.2011. The Efficcy of Diabetes Patient Education and Self Managemnt Education in Type 2 Diabetes. Canadian Journal Of Diabetes Volume 35 (1): p. 46-53.

Norris, S. L., et al. 2002. Increasing Diabetes Self-Management Education in Community Settings. Am J Prev Med Volume 22 (4S): p. 39-66.

Notoadmojo, Soekidjo. 2010. Health Research Methodology. Jakarta: Rineka Cipta. 
Notoatmodjo, P. D. 2010. Health Behavioral Science. Jakarta: Rineka Cipta.

Notoatmodjo, P. D. 2010. Health Research Methodology. Jakarta: Rineka Cipta.

Nursalam. 2008. Concept and Application of Research Methodology of Nursing Science. Jakarta: Salemba Medika.

Perkeni.2011. Consensus Control and Prevention of Type 2 Diabetes Mellitus in Indonesia 2011. (http://www.Perkeni.com) (accessed on 09 January 2017).

Peter. 2006. Diabetes Healthy Diet According to Blood Type. Jakarta: Delapratasa Publishing.

Qurratuaeni. 2009. factors related to the controlled blood sugar levels in Diabetes Mellitus patients at Fatmawati Central General Hospital (RSUP) Jakarta. Jakarta: UIN SYARIF HIDAYATULLAH.

Ratna, M. 2000. Endocrine Faal. Jakarta: CV. Sagung Seto.

Riskesdas. 2013. Basic Health Research. (http://www.RisetHealthBaseline.co m) (accessed on January 09, 2017).

Riyadi. 2008. Nursing Care In Patients With Exocrine and Endocrine Disorders In Pancreas. Yogyakarta: Graha Ilmu.

Rondhianto. 2011. Influence of Diabetes Self Management Education in Discharge Planning against Self Efficacy and Self Care Behavior Diabetes Mellitus type 2 patient [thesis]. Surabaya: Master Program of Nursing Faculty of the Nursing University of Airlangga.

Saryono. 2010. Health Research Methodology. Yogyakarta: partner of Cendika Press

Setiadi. 2013. Concept and Practice of Nursing Research Writing Second Edition. Yogyakarta: Graha science.

Sidani, S. \& Fan, L. 2009. Effectiveness of Diabetes Self-management Education Intervention Elements: A Meta-analysis. Canadian Journal of Diabetes Volume 33 (1): p. 18-26.

Sugiyono. 2008. Quantitative Research Methods, Qualitative and R \& D.Bandung. Alfabeta.

Sulistyowati, E. 2009. Influence of Health Education About Diet Therapy On Knowledge And Control Of Blood Sugar Level In Diabetes Mellitus At Work Area of Puskesmas Toroh 1 Grobogan District. Surakarta: FACULTY OF HEALTH SCIENCE UNIVERSITY

MUHAMMADIYAH.

Wahid, R. A. 2106. Influence of Diabetes Health Education Self Management Education (DSME) on Blood Sugar Levels Patient DM Type II Pronalis Puskesmas Gajahan Surakarta. Surakarta: STIKES KUSUMA HUSADA.

Wawan, A., Dewi, M., 2010. Theory and Measurement of Knowledge, 
Attitude, and Human Behavior.

Yogyakarta: Nuha Medika.

Yuanita, Alvinda. 2013. The Influence of

Diabetes Self Management

Education (DSME) Against Risk of

Diabetic Ulcers In Patients Outside

With Diabetes Mellitus (DM) Type 2

In RSD dr. Soebandi Jember.

Jember: UNIVERSITY JEMBER 